\title{
Nitrous oxide emissions in a biofilm loaded with different mixtures of concentrated household wastewater
}

\author{
D. Todt $\cdot$ P. Dörsch
}

Received: 23 October 2014/Revised: 7 January 2015/Accepted: 14 February 2015/Published online: 4 March 2015

(C) Islamic Azad University (IAU) 2015

\begin{abstract}
Aerobic biofilm systems are increasingly used for household wastewater treatment, but little is known about their potential to emit nitrous oxide in response to different loading conditions. We studied nitrification and nitrous oxide production in a biofilm reactor that was continuously fed with three different mixtures of household wastewater. Higher proportions of blackwater increased nitrification activity, which resulted in enhanced nitrite accumulation and nitrous oxide emissions. Applying a conceptual biofilm model together with the results of ancillary batch incubations suggested that this was caused by a higher proportion of slowly degradable compounds in blackwater. Increasing amounts of blackwater would result in less oxygen depletion by heterotrophic degradation in outer biofilm layers, leading to nitrite accumulation by enhanced ammonia oxidation as well as electron limitation of denitrification in anoxic biofilm layers. Under such conditions, nitrifier denitrification and incomplete heterotrophic denitrification would be the prevailing sources of nitrous oxide emission. These assumptions are supported by an exponential increase in the determined emission factor (nitrous oxide relative to oxidized ammonia), which accounted for 0.7 with $20 \%$ blackwater, 1.1 with $50 \%$ blackwater, and 8.5 with $100 \%$ blackwater in the wastewater load.
\end{abstract}

Keywords Biofilm - Nitrous oxide $\cdot$ Nitric oxide · Household wastewater Blackwater - Greywater

D. Todt $(\bowtie) \cdot$ P. Dörsch

Department of Environmental Sciences, Norwegian University of Life Sciences, Frognerbakken 3, 1432 Ås, Norway

e-mail: danitodt@gmail.com

\section{Introduction}

Due to their robustness, aerobic biofilm systems are gaining increasing popularity for onsite treatment of household wastewater (Azizi et al. 2013). Household wastewater has usually higher concentrations of nitrogen and organic compounds and a significantly lower $\mathrm{C} / \mathrm{N}$ ratio than municipal wastewater, but the composition varies with source depending on both infrastructure and user habits. In regions with water shortage, separation and reuse of particular wastewater fractions is gaining importance which can result in highly concentrated sewage (Penn et al. 2012). During biological treatment, highly concentrated household wastewaters, especially pure blackwater, pose an environmental risk by potentially being a strong source for nitrous oxide $\left(\mathrm{N}_{2} \mathrm{O}\right.$; de Graaff et al. 2010; Itokawa et al. 2001). Nitrous oxide is a strong greenhouse gas (ICCP 2001) and involved in the depletion of the stratospheric ozone layer (Ravishankara et al. 2009). In the last decade, $\mathrm{N}_{2} \mathrm{O}$ emissions have gained increasing awareness in design and operation of wastewater treatment plants (Kampschreur et al. 2009; Schreiber et al. 2012). Hence, more knowledge is needed to understand how process dynamics of $\mathrm{C}$ and $\mathrm{N}$ turnover in highly charged biofilms control $\mathrm{N}_{2} \mathrm{O}$ formation and emission.

Most of the present knowledge on $\mathrm{NO}$ and $\mathrm{N}_{2} \mathrm{O}$ emissions in wastewater treatment processes originates from pure culture studies (e.g. Beaumont et al. 2002; Poth and Focht 1985; Schmidt 2009) or systems with suspended biomass (activated sludge; (Kampschreur et al. 2009). Only few studies have investigated $\mathrm{N}_{2} \mathrm{O}$ in biofilm systems that support complex biomass interactions driven by diffusion limited substrate fluxes. Most of these studies dealt with pure nitrifying biofilm systems dominated by autotrophic communities (de Graaff et al. 2010; Yang et al. 2013). So 
far, little research has been dedicated to $\mathrm{N}_{2} \mathrm{O}$-emitting processes in more complex heterogeneous communities of interacting heterotrophic and autotrophic organisms typical for biofilm systems loaded with domestic wastewater, with the notable exception of a recent bench-scale study using synthetic substrates (Schreiber et al. 2009). However, synthetic substrates may not be fully representative for real household wastewaters, which constitute a complex mixture of mineral and organic molecules (Dulekgurgen et al. 2006; Hocaoglu et al. 2010).

The objective of the present study was to assess $\mathrm{N}$ gas production $\left(\mathrm{NO}, \mathrm{N}_{2} \mathrm{O}\right)$ in a biofilm system loaded with different mixtures of concentrated household wastewater, simulating inlet conditions typical for onsite applications in systems with source separation and reuse of greywater. For this purpose, a long-term experiment with three mixtures of source separated sewage from a student dormitory was set up as a moving bed biofilm reactor (MBBR). MBBR systems are simple to operate and monitor at steady state and therefore often used in applied biofilm experiments (e.g. de Graaff et al. 2010; Fux et al. 2004). Moreover, simple MBBR systems are typically used in decentralized applications, in which nitrification is not necessarily the main purpose but often occurs as a side effect (Daude and Stephenson 2003). Our study used an experimental MBBR which was operated as heterotrophic biofilm system. To explore the impact of wastewater compositions and system conditions on $\mathrm{N}$ gas production $\left(\mathrm{NO}, \mathrm{N}_{2} \mathrm{O}\right)$ in more detail, additional bench-scale incubations of biofilm material were carried out. The research of this study was carried out in the period from March to June 2013 at the Norwegian University for Life Sciences in $\AA$ s, Norway.

\section{Materials and methods}

Experimental setup of the MBBR reactor system

A continuous flow MBBR system with a well-established biofilm was loaded with three different wastewater mixtures according to Table 1 . The MBBR system comprised two sequential reactor tanks (R1 and R2) of $200 \mathrm{~L}$ volume each, filled to $60 \%$ with a $600 \mathrm{~m}^{2} \mathrm{~m}^{-3}$ carrier material (BWTX, Biowater, Tønsberg, Norway). The tanks were aerated via coarse diffusers ( $3 \mathrm{~mm}$ orifice) from the bottom of the reactor tanks. R1 was equipped with 16 diffusers and R2 with 12 diffusers. The air flow in the reactor tanks, $Q_{\text {airR }}$, was estimated based on the number of diffusers and the total air flow measured with a flow meter (SS 30.300, SCHMIDT, St. Georgen, Germany) at the inlet of the tanks. Based on the measured total air flow of $8840 \pm 100 \mathrm{~L} \mathrm{~h}^{-1}$, a $Q_{\text {air }}$ of $5050 \mathrm{~L} \mathrm{~h}^{-1}$ was estimated for $\mathrm{R} 1$ and $3790 \mathrm{~L} \mathrm{~h}^{-1}$ for R2. Prior to the experiment, the reactor was operated for 6 months on a loading regime equal to the first loading period. The aeration ensured a DO in the range of $3-5 \mathrm{mg} \mathrm{L}^{-1}$ in both reactor tanks during the entire experimental period.

The wastewater was taken from a nearby student dormitory equipped with source separating sanitation (Todt et al. 2014). The inlet mixtures (Table 1) were established once per day with help of peristaltic pumps (Bredel SPX, Whatson Marlos, Falmouth, UK) in a third stirred tank from which the first reactor tank was fed. Mixing and feeding was controlled by a PLC. The inlet flow was measured with a flow meter (Optiflux2000' Krohne, Duisburg, Germany).

\section{Liquid analysis and calculation of fluxes}

For the liquid analysis, grab samples were taken from the inlet tank and from the reactor tanks R1 and R2. Soluble COD and nitrogen species (total ammonia nitrogen (TAN), $\mathrm{NO}_{2}{ }^{-}, \mathrm{NO}_{3}{ }^{-}$) were analyzed by spectrophotometric test kits from Hach-Lange, Berlin, Germany (LCK314, LCK114, LCK304, LCK341, LCK339). The samples were filtered through 1.2- $\mu \mathrm{m}$ glassfiber filters (Whatman ${ }^{\mathrm{TM}} \mathrm{GF}$ C) prior to analysis. Fluxes of dissolved $\mathrm{N}$ compounds and COD in each tank were calculated as the difference in measured concentrations between inlet and R1 or R1 and $\mathrm{R} 2$, respectively. To account for differences in short-term inlet variations, the fluxes where calculated as weekly averages of 3-5 measurements. Statistical variation was estimated with help of random variable algebra, assuming normal distribution for samples taken within the same week.

Table 1 Loading periods P1-P3 in 2013 with different mixtures of household wastewater, hydraulic loading rate $(Q)$, and hydraulic retention time (HRT) in the MBBR system

\begin{tabular}{lllll}
\hline & Blackwater fraction & Greywater fraction & $Q$ & HRT \\
\hline First period P1 (February 5-March 12) & $20 \%\left(324 \mathrm{~L} \mathrm{day}^{-1}\right)$ & $80 \%\left(1167 \mathrm{~L} \mathrm{day}^{-1}\right)$ & $1487 \mathrm{~L} \mathrm{day}^{-1}$ & $0.26 \mathrm{day}^{-1}$ \\
Second period P2 (April 5-April 19) & $50 \%\left(309 \mathrm{~L} \mathrm{day}^{-1}\right)$ & $50 \%\left(318 \mathrm{~L} \mathrm{day}^{-1}\right)$ & $627 \mathrm{~L} \mathrm{day}^{-1}$ \\
Third period P3 (April 25-May 16) & $100 \%\left(320 \mathrm{~L} \mathrm{day}^{-1}\right)$ & - & $320 \mathrm{~L} \mathrm{day}^{-1}$ & $0.64 \mathrm{day}^{1.26 \mathrm{day}}$ \\
\hline
\end{tabular}


Gas sampling and analysis

In each of the reactor tanks, gas samples were taken from two different sampling points. For the first sampling point, a 500-mm-long and 75-mm-wide cylinder was immersed $5 \mathrm{~cm}$ into the reactor to collect the air leaving the bulk liquid. Gas samples were taken with an injection needle from the center of the cylinder $250 \mathrm{~mm}$ above the water level. The second sampling point was established in the ventilation outlet pipe of each of the reactor tanks. The funnel method ensured collection of air that had passed the reactor with no dilution from ambient air, while the small area covered by the funnel was probably not representative for the average gas flow across the reactor. The sample drawn from the ventilation system, on the other hand, can be assumed to be representative for the whole reactor surface, but is sensitive to dilution by ambient air leaking into the ventilation pipes. Average values were calculated from both sampling points, unless the deviation in gas concentration was $>20 \%$, in which case the measurements were discarded. In addition to the reactor samples, a third sampling point was established at the inlet of the aeration pump. The $\mathrm{N}_{2} \mathrm{O}$ flux from a particular reactor tank, $J_{\mathrm{N}_{2} \mathrm{O}-\mathrm{Ri}}$ (mg $\mathrm{N} \mathrm{m}^{-2}$ biofilm $\mathrm{h}^{-1}$ ), was calculated based on the concentration difference between the airstream leaving $\left(\mathrm{ppmv}_{\mathrm{SjRi}}\right)$ and the airstream entering a reactor tank (pp$\left.\mathrm{mv}_{\mathrm{in}}\right)$, the air flow rate in the reactor tank $Q_{\text {airRi }}\left(\mathrm{m}^{3} \mathrm{~h}^{-1}\right)$, the air temperature in the head space above the reactor tanks $T_{\mathrm{Ri}}(\mathrm{K})$, the gas constant $R\left(\mathrm{~J} \mathrm{~K}^{-1} \mathrm{~mol}^{-1}\right)$, and the active surface area $A\left(\mathrm{~m}^{2}\right)$ (Eq. 1).

$$
\begin{aligned}
J_{\mathrm{N}_{2} \mathrm{O}-\mathrm{Ri}}= & \left(\mathrm{ppmv}_{\mathrm{S}_{\mathrm{jRi}}}-\mathrm{ppmv}_{\mathrm{in}}\right) \times Q_{\mathrm{airRi}} \\
& \times \frac{1}{\left(R \times T_{\mathrm{Ri}}\right)} \times 28 \times \frac{1}{A}
\end{aligned}
$$

The gas samples were stored and transported in helium washed, pre-evacuated septum vials (Model 10-CV-Crimp, Chromacol, Herts). $\mathrm{N}_{2} \mathrm{O}$ was analyzed on a gas chromatograph (Model 7890A, Agilent, Santa Clara, US) using an electron capture detector (ECD) for low $(<4 \mathrm{ppmv})$ and a thermal conductivity detector for high $\mathrm{N}_{2} \mathrm{O}$ concentrations. For separation of $\mathrm{N}_{2} \mathrm{O}$ from air, a 20-m-wide bore Poraplot Q capillary $(0.53 \mathrm{~mm})$ column at $38{ }^{\circ} \mathrm{C}$ with backflushing and $\mathrm{He}$ as carrier gas was used. The ECD conditions were $375{ }^{\circ} \mathrm{C}$ with $17 \mathrm{~mL} \mathrm{~min}{ }^{-1} \mathrm{ArCH}_{4}$ (90/ $10 \mathrm{vol} \%$ ) as makeup gas.

Ex-situ studies to explore biofilm processes

Additional short-term $(<5 \mathrm{~h})$ batch incubations in air with different $\mathrm{C}$ and $\mathrm{N}$ additions were performed in constantly stirred 120-mL serum bottles loaded with three biofilm media grits and 20-mL incubation liquid, mimicking a filling degree comparable to that of the reactor tanks. For each incubation experiment, fresh biofilm media grits were taken from the pilot-scale system. The bottles were crimpsealed with butyl rubber septa and incubated under constant magnetic stirring $(300 \mathrm{rpm})$ at $15{ }^{\circ} \mathrm{C}$ in a water bath. Headspace was sampled automatically every $50 \mathrm{~min}$ by an autosampler and analyzed by a gas chromatograph and a connected chemoluminescence $\mathrm{NO}$ analyzer for $\mathrm{N}_{2} \mathrm{O}$ and NO, respectively (Molstad et al. 2007).

To obtain more information about the kinetics of organic $\mathrm{C}$ and $\mathrm{N}$ depletion, a 1.4-L open bench-scale MBBR was set up. The cylindrical reactor of $75 \mathrm{~mm}$ diameter was aerated from the bottom with a coarse diffuser and an aeration pump having a capacity of $0.2 \mathrm{~N} \mathrm{~m}^{3} \mathrm{~h}^{-1}$. For each run, the reactor was filled with $800 \mathrm{~mL}$ fresh biofilm media taken from the second reactor tank corresponding to a filling degree of $60 \%$.

Table 2 gives an overview over the treatments used in the incubations experiments. The mixtures A1 and B1 simulated loading conditions in the second reactor tank during period 1 and 2, respectively. The inlet mixtures $\mathrm{C} 1$ and $\mathrm{C} 2$ simulated a higher organic loading rate, while $\mathrm{C} 2$ was amended with $\mathrm{KNO}_{2}$ to test the effect $\mathrm{NO}_{2}{ }^{-}$accumulation on $\mathrm{N}$ gas production. To explore the biofilm processes with a more defined substrate, a sterile basis medium (synthetic mixtures D1) was prepared by filtering

\begin{tabular}{|c|c|c|c|c|c|c|c|}
\hline & Period & Incubation mixture & Addition & $\begin{array}{l}\mathrm{COD}_{\text {soluble }} \\
\left(\mathrm{mg} \mathrm{O}_{2} \mathrm{~L}^{-1}\right)\end{array}$ & TAN (mg N L $\left.{ }^{-1}\right)$ & $\mathrm{NO}_{2}^{-}\left(\mathrm{mg} \mathrm{N} \mathrm{L}^{-1}\right)$ & $\mathrm{NO}_{3}{ }^{-}\left(\mathrm{mg} \mathrm{N} \mathrm{L}^{-1}\right)$ \\
\hline A1 & P1 & $\begin{array}{l}50 \% \mathrm{R} 1 \\
50 \% \mathrm{R} 2\end{array}$ & None & 205 & 275 & 1.4 & 0.75 \\
\hline B1 & $\mathrm{P} 2$ & $\begin{array}{l}50 \% \mathrm{R} 1 \\
50 \% \mathrm{R} 2\end{array}$ & None & 332 & 560 & 30 & 7 \\
\hline $\mathrm{C} 1$ & $\mathrm{P} 2$ & Sewage P2 1:2 diluted & None & 407 & 223 & - & 1 \\
\hline $\mathrm{C} 2$ & & & $\mathrm{NO}_{2}^{-}$ & 407 & 223 & 27 & 1 \\
\hline D1 & $\mathrm{P} 2$ & Synthetic & $\mathrm{NH}_{4}^{+}$ & 464 & 332 & - & 2 \\
\hline
\end{tabular}

Table 2 Incubation mixtures used in the incubation trials 
and diluting (1:20) a thermally treated $\left(90{ }^{\circ} \mathrm{C}\right.$ for $\left.20 \mathrm{~min}\right)$ sewage mixture of $\mathrm{P} 2$, to which acetate and $\mathrm{NH}_{4} \mathrm{Cl}$ was added to reach TAN and COD values similar to the inlet mixtures $(\mathrm{C} 1, \mathrm{C} 2)$.

Ammonia fluxes related to biological $\mathrm{N}$ transformation $\left(J_{\mathrm{NH}_{4} \mathrm{oxi}}\right)$

To determine the net TAN flux related to biological oxidation $\left(J_{\mathrm{NH}_{4} \text { oxi }}\right)$, the TAN fraction lost by stripping of $\mathrm{NH}_{3}\left(J_{\mathrm{NH}_{3} \mathrm{~g}}\right)$ and by immobilization into the growing biomass $\left(J_{\mathrm{NH}_{4} i m m o b}\right)$ were estimated and subtracted from the gross flux of TAN ( $J_{\mathrm{NH}_{4} \text { gross }}$ ) which was observed between inlet and R1 or R2 and R1 (Eq. 2). For batch incubation in closed bottles, $J_{\mathrm{NH}_{3} \mathrm{~g}}$ was assumed to be negligible, and only, $J_{\mathrm{NH}_{4} \text { immob }}$ was considered.

$J_{\mathrm{NH}_{4} \mathrm{oxi}}=J_{\mathrm{NH}_{4} \text { gross }}-J_{\mathrm{NH}_{3} \mathrm{~g}}-J_{\mathrm{NH}_{4} \mathrm{immob}}$

Heterotrophic growth $\mathrm{J}_{\mathrm{NH}_{4} \text { immob }}$ (Eq. 3) was estimated based on a yield coefficient $Y_{\text {het }}$ of $0.54 \mathrm{~g} \mathrm{COD} \mathrm{g}^{-1}$ COD and a nitrogen content $\mathrm{N}_{\text {biomass }}$ of $0.07 \mathrm{~g} \mathrm{~N} \mathrm{~g}^{-1} \mathrm{COD}$ biomass (Gujer et al. 1999).

$J_{\mathrm{NH}_{4} \text { immob }}=J_{\mathrm{COD}} \times Y_{\text {het }} \times \mathrm{N}_{\text {biomass }}$

The flux of stripped $\mathrm{NH}_{3}\left(J_{\mathrm{NH}_{3} \mathrm{~g}}\right)$ was approached by measured $\mathrm{NH}_{4}{ }^{+}$and by the aeration volume and its mass transfer rate from the water phase to the air (Zhang et al. 1994) according to Eq. 4 :

$J_{\mathrm{NH}_{3} \mathrm{~g}}=\left[\mathrm{NH}_{3}\right]_{\text {liquid }} \times \frac{1}{\mathrm{kH}_{\mathrm{CC}}} \times Q_{\text {airRi }}$

with $\mathrm{kH}_{\mathrm{cc}}$ being the temperature corrected Henry constant of $\mathrm{NH}_{3}$ (Aarnink and Elzing 1998) and $\left[\mathrm{NH}_{3}\right]_{\text {liquid }}$ the dissolved concentration of free ammonia calculated according to Anthonisen et al. (1976).

\section{Results and discussion}

Inlet mixtures and loadings

The loading of the tanks was governed by the natural variation in composition with raw wastewater from the student dormitories. In general, soluble organic compounds (expressed as COD) showed a higher variation than $\mathrm{NH}_{4}{ }^{+}$, and its variability increased from $\mathrm{P} 1$ to $\mathrm{P} 3$ (Fig. 1). $\mathrm{P} 1$ and $\mathrm{P} 3$ showed a comparable COD/TAN ratio ranging from 2.2 to 2.7, while the ratio was significantly lower in P2 ranging from 1.4 to 2.1 (Fig. 1). The average loads based on the measured TAN and COD concentrations shown in Fig. 1 and the hydrological loading rate $\mathrm{Q}$ given in Table 1 were $1021 \pm 118 \mathrm{~g} \mathrm{O}_{2}$ day $^{-1}$ and $411 \pm 26 \mathrm{~g} \mathrm{~N} \mathrm{day}^{-1}$ for P1, $700 \pm 168 \mathrm{~g} \mathrm{O}_{2}$ day $^{-1}$ and $400 \pm 36 \mathrm{~g} \mathrm{~N}$ day $^{-1}$ for P2 and $860 \pm 68 \mathrm{~g} \mathrm{O}_{2}$ day $^{-1}$ and $358 \pm 25 \mathrm{~g} \mathrm{~N}$ day $^{-1}$ for $\mathrm{P} 3$ for R1 and R2, respectively. During the first half of P3, soluble COD was relatively stable around $2500 \mathrm{mg} \mathrm{O}_{2} \mathrm{~L}^{-1}$ before it increased to $3000 \mathrm{mg} \mathrm{O} \mathrm{O}^{-1}$ (Fig. 1c), likely because unusually high ambient temperatures during this period supported hydrolysis of particulate matter in the sewer system and the mixing tank.

Nitrification activity and controlling factors

Both reactor tanks showed considerable ammonia oxidation activity as indicated by the accumulation of $\mathrm{NO}_{2}{ }^{-}$. Also $\mathrm{NO}_{2}{ }^{-}$oxidation to $\mathrm{NO}_{3}{ }^{-}$took place but at a lower rate than ammonia oxidation, especially during P3 (Fig. 2). With a reactor $\mathrm{pH}$ of $8.0-8.5$, the oxidation of $\mathrm{NO}_{2}{ }^{-}$was most likely inhibited by free $\mathrm{NH}_{3}$ as reported by earlier studies (e.g. Fux et al. 2004). Applying a classical inhibition model (Anthonisen et al. 1976) to our reactor tanks resulted in a $20-30 \%$ inhibition of $\mathrm{NO}_{2}^{-}$oxidation for $\mathrm{P} 1$,
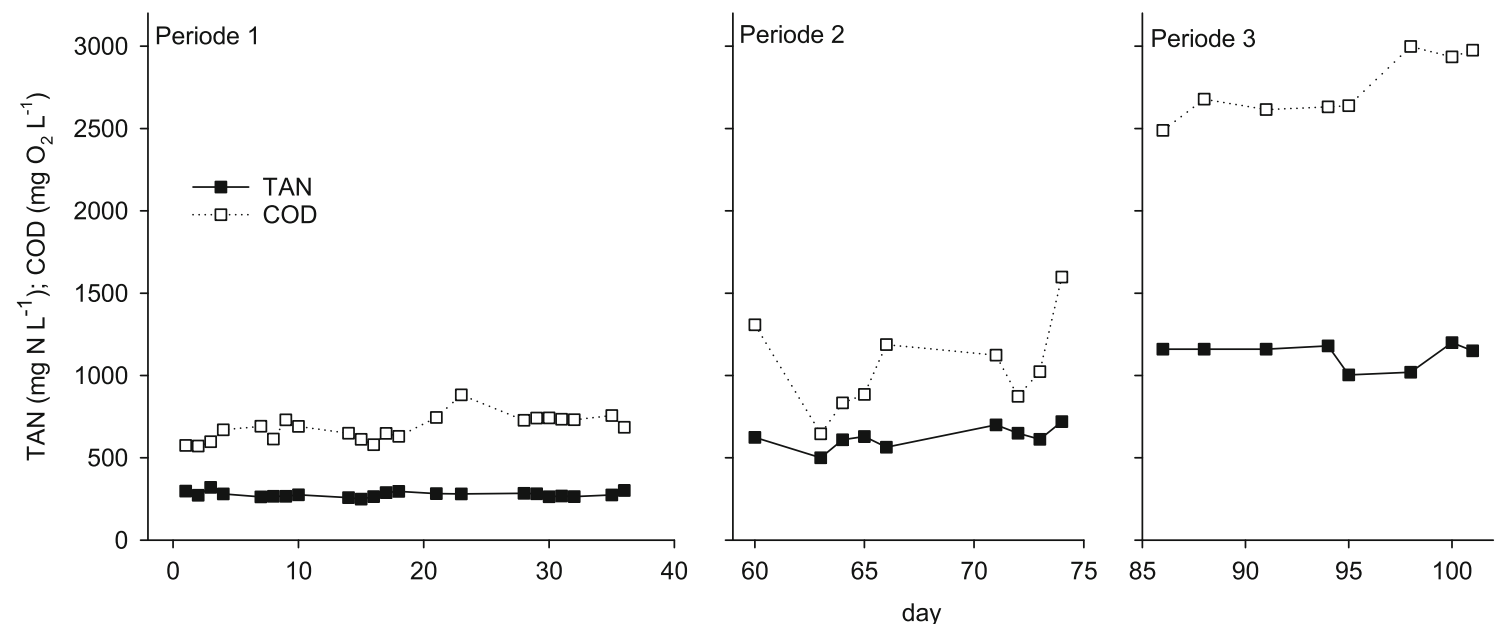

Fig. 1 Concentration of soluble COD and TAN in the inlet mixtures during the loading periods P1 (day 0-40), P2 (day 60-75) and P3 (day 85-101) 

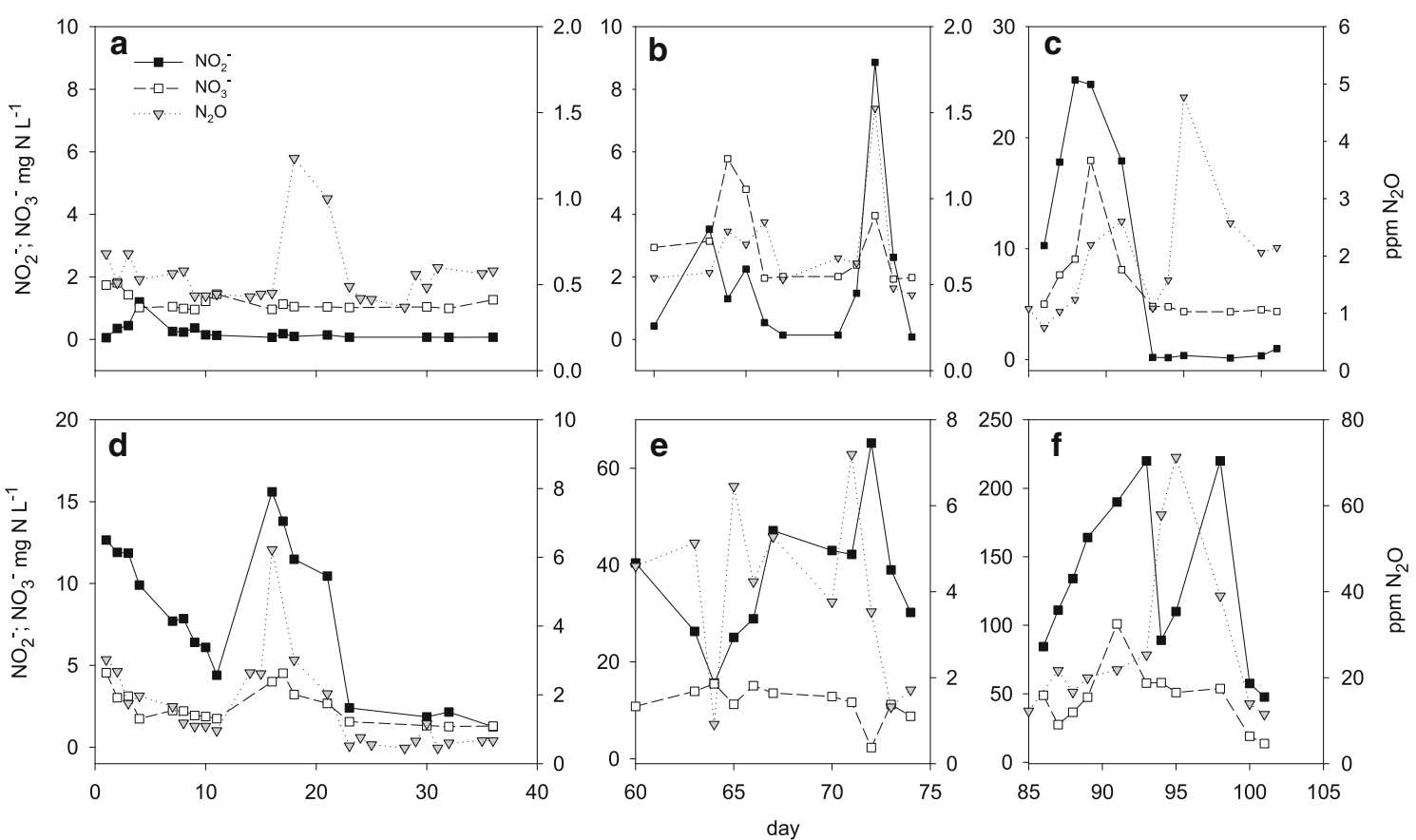

Fig. 2 Dynamics of $\mathrm{NO}_{2}{ }^{-}, \mathrm{NO}_{3}{ }^{-}$, and $\mathrm{N}_{2} \mathrm{O}$ concentrations in the first (a-c) and second (d-f) reactor tank during loading periods P1 (a, d), $\mathrm{P} 2$ $(\mathbf{b}, \mathbf{e})$, and P3 (c, f), Note different scaling for $y$-axes

50-60 \% for P2 and $60-70 \%$ for $\mathrm{P} 3$, supporting the assumption that $\mathrm{NH}_{3}$ inhibited nitrite oxidation.

The estimated nitrification and denitrification activity was evaluated with help of a simplified biofilm modeling approach based on Wanner et al. (2006). The model predicts oxygen limitation of heterotrophic activity when the coefficient $Y_{\mathrm{S}, \mathrm{O}_{2}}$ exceeds 1 (Eq. 5). Under such conditions, no oxygen is available for ammonia oxidation by nitrifying organism in deeper biofilm layers.

$Y_{\mathrm{S}, \mathrm{o}_{2}}=\left(1-Y_{\text {het }, \mathrm{O}_{2}}\right) \frac{D_{\mathrm{S}}}{D_{\mathrm{O}_{2}}} \frac{S_{\mathrm{org}}}{S_{\mathrm{O}_{2}}}$

The bulk liquid $\mathrm{O}_{2}$ concentration $\left(S_{\mathrm{O}_{2}}\right)$ was parameterized with measured values in $\mathrm{R} 1$ and the diffusion coefficient for $\mathrm{O}_{2} \quad\left(D_{\mathrm{O}_{2}}\right)$ with $2.1 \times$ $10^{-4} \mathrm{~m}^{2}$ day $^{-1}$ (Wanner and Reichert 1996). $D_{\mathrm{S}}$ was parameterized with $0.43 \times 10^{-4} \mathrm{~m}^{2}$ day $^{-1}$ (Logan et al. 1987) which refers to organic molecules of a size of $100-500 \mathrm{kDa}$, approximately reflecting the average molecule size found for soluble compounds of a household wastewater (Dulekgurgen et al. 2006). The substrate concentration $\left(S_{\text {org }}\right)$ was calculated as the difference in soluble COD between R1 and R2 with the assumption that all readily degradable soluble organics were depleted in R2.

Following the stratified biofilm model (Wanner et al. 2006; Wanner and Reichert 1996), competition for $\mathrm{O}_{2}$ with heterotrophs in the biofilm was likely the major controlling factor for the $\mathrm{N}$ turnover in $\mathrm{R} 1$, as supported by the inverse relationship between $\mathrm{J}_{\mathrm{HN} 4 \mathrm{oxi}}$ and the oxygen limitation coefficient $Y_{\mathrm{S}_{\mathrm{O}}}$ (Fig. 3). Elenter et al. (2007) reported an ammonia oxidation rate corresponding to a $J_{\mathrm{NH}_{4} \text { oxi }}$ of $60 \mathrm{mg} \mathrm{N} \mathrm{m}^{-2} \mathrm{~h}^{-1}$ for a $Y_{\mathrm{S}, \mathrm{O}_{2}}$ of 0.3 and $8 \mathrm{mg} \mathrm{N} \mathrm{m}^{-2} \mathrm{~h}^{-1}$ for $Y_{\mathrm{S}, \mathrm{O}_{2}}$ of 1.1 in a MBBR with mixed load. In our study, estimated $Y_{\mathrm{S}, \mathrm{O}_{2}}$ values ranged from 1.0 to 2.9 (first and third quartile of graph in Fig. 3) and supported a $J_{\mathrm{NH}_{4} \text { oxi }}$ ranging from 2 to $18 \mathrm{mg} \mathrm{N} \mathrm{m}^{-2} \mathrm{~h}^{-1}$ (Fig. 3), which is in the same order of magnitude. This suggests that our approach to estimate $J_{\mathrm{NH}_{4} \text { oxi }}$ as decrease in TAN corrected for $\mathrm{NH}_{3}$ volatilization and microbial immobilization is reasonable.

In R1, we observed a marked imbalance between $J_{\mathrm{NH}_{4} \text { oxi }}$ and $J_{\mathrm{NO}_{2}+\mathrm{NO}_{3}}$ throughout the entire experiment (Fig. 3), suggesting that a major fraction accounting for $60-95 \%$ of $J_{\mathrm{NH}_{4} \text { oxi }}$ was transformed into gaseous $\mathrm{N}$ compounds by denitrification in deeper, anoxic biofilm zones. However, the occurrence of denitrification may be questioned during periods of $Y_{\mathrm{S}, \mathrm{O}_{2}}<1$, because this value predicts that all substrates $\left(S_{\text {org }}\right)$ are depleted in aerobic biofilm zones, and no electron donor is left for denitrification in anoxic zones. Under such conditions, endogenous residues as well as soluble organic exudates from AOB have been pointed out as a potential energy source for denitrification (Kindaichi et al. 2004; Rittmann et al. 1994). However, if the 

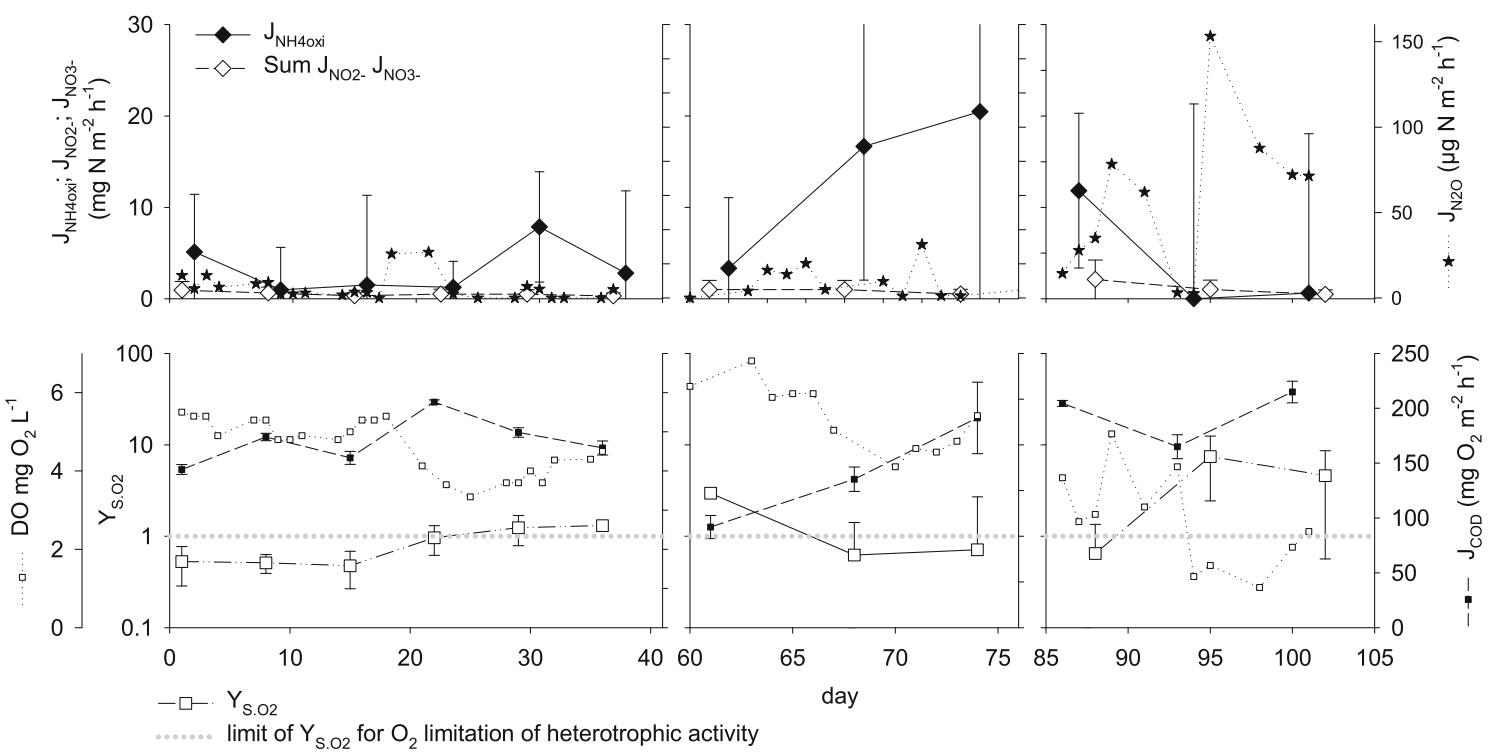

Fig. 3 Upper panel calculated $\mathrm{N}$ fluxes related to ammonia oxidation $\left(J_{\mathrm{NH}_{4} \text { oxi }}\right)$ and release of $\mathrm{NO}_{2}^{-}$and $\mathrm{NO}_{3}{ }^{-}$into bulk liquid and measured $\mathrm{N}_{2} \mathrm{O}$ flux in the second reactor tank (periods 1-3). The lower panel shows the calculated oxygen limitation coefficient $Y_{\mathrm{S}, \mathrm{O}_{2}}$ for nitrification activity and measured DO. The calculated values are shown as weakly means with error bars denoting the variation (SD). For the directly measured parameters $\left(J_{\mathrm{N}_{2} \mathrm{O}}, \mathrm{DO}\right)$, individual measure points are displayed
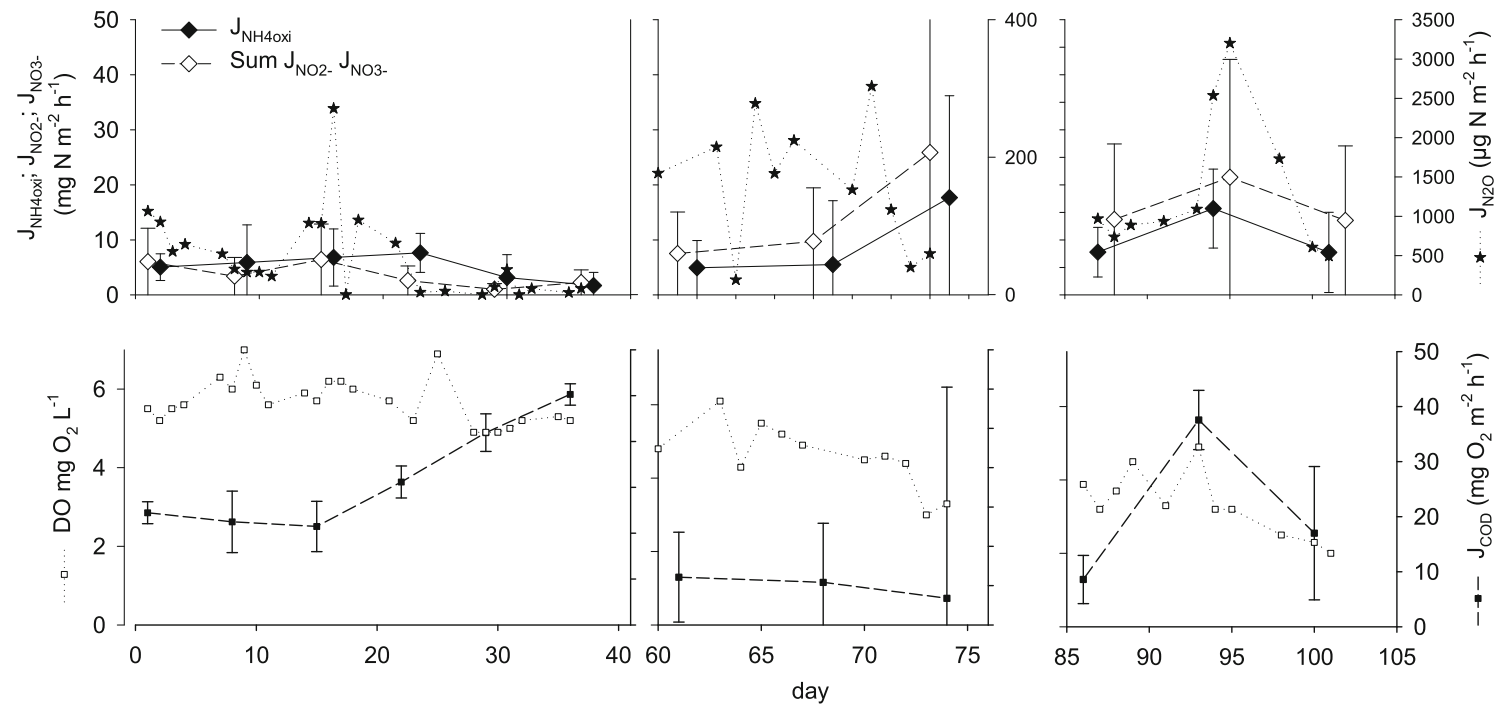

Fig. 4 Upper panel calculated $\mathrm{N}$ fluxes related to ammonia oxidation $\left(J_{\mathrm{NH}_{4} \text { oxi }}\right)$ and release of $\mathrm{NO}_{2}{ }^{-}$and $\mathrm{NO}_{3}{ }^{-}$into bulk liquid and measured $\mathrm{N}_{2} \mathrm{O}$ flux in the second reactor tank (periods $1-3$ ). The lower panel shows weekly means of the calculated COD flux and

contribution of those internal sources should have been significant, a substantially higher denitrification activity would have been expected also in R2 in which no significant imbalance between $J_{\mathrm{NH}_{4} \text { oxi }}$ and the sum of $J_{\mathrm{NO}_{2}}$ and $J_{\mathrm{NO}_{3}}$ was found (Fig. 4). We therefore believe that anoxic biofilm zones in R1 were supplied with electron donors measured DO values. The calculated values are shown as weakly means with error bars denoting the variation (SD). For the directly measured parameters $\left(\mathrm{J}_{\mathrm{N}_{2} \mathrm{O}}, \mathrm{DO}\right)$, individual measure points are displayed

during transient shifts in organic load (Fig. 1) which resulted in $Y_{\mathrm{S}, \mathrm{O}_{2}}$ values fluctuating around one (Fig. 3).

In R2, heterotrophic activity was likely permanently substrate limited, resulting in $Y_{\mathrm{S}, \mathrm{O}_{2}}$ values $\ll 1$, as indicated by the low $\mathrm{J}_{\mathrm{COD}}$ (Fig. 4), which was one order of magnitude lower than in R1 (Fig. 3), as well as by the 
absence of any relationship between $J_{\mathrm{COD}}$ and DO (Fig. 4). Considering the low heterotrophic activity, it is surprising that $J_{\mathrm{NH}_{4} \text { oxi }}$ in R2 was not significantly higher than in $\mathrm{R} 1$ as a $Y_{\mathrm{S}, \mathrm{O}_{2}} \ll 1$ would suggest. This phenomenon might be a result of different biofilm structures and detachment rates. A qualitative optical analysis of the media grits showed that the biofilm in R1 was relatively thin, likely reflecting the high turbulence and shear forces in R1. In R2, the turbulence was lower, and the biofilm looked fluffier and markedly thicker. This difference is also supported by the measured biomass dry weight which was 4-9 $\mathrm{g} \mathrm{m}^{-2}$ for $\mathrm{R} 1$ and $13-27 \mathrm{~g} \mathrm{~m}^{-2}$ for R2. Due to their higher resistance against biomass detachment, AOB clusters may persist in surface-near biofilm layers and thus decrease the degree of biomass stratification if frequent detachment events take place (Elenter et al. 2007). This may have facilitated the interaction of particulate organics with the biofilm in R1, thus resulting in additional $\mathrm{O}_{2}$ depletion in outer biofilm zones by hydrolysis and degradation of particulate COD, which was not captured in our study.

Regardless of the magnitude of $J_{\mathrm{NH}_{4} \text { oxi }}$, the presence of detectable $\mathrm{NO}_{2}{ }^{-}$and $\mathrm{NO}_{3}{ }^{-}$in both reactor tanks (Fig. 2) suggests that nitrification activity is unavertable in aerobic biofilm systems loaded with mixtures of household wastewaters with frequent variations in organic and nitrogen load. Even though the estimated reaction rates $\left(J_{\mathrm{NH}_{4} \text { oxi }}\right)$ were small relative to $\mathrm{N}$ removal, they are significant in terms of $\mathrm{N}_{2} \mathrm{O}$ emissions as indicated by the high $\mathrm{N}_{2} \mathrm{O}$ emissions of the reactor tanks (Fig. 2).

\section{$\mathrm{N}_{2} \mathrm{O}$ fluxes and emission factor}

In both reactor tanks, high $\mathrm{N}_{2} \mathrm{O}$ concentrations were detected in the exhaust air, which were fivefold to tenfold higher in R2 than in R1 (Fig. 2). In R1, the calculated $J_{\mathrm{N}_{2} \mathrm{O}}$ accounted for $0.2-0.7 \%$ of $J_{\mathrm{NH}_{4} \text { oxi }}$ in average, while this emission factor was substantially higher in R2 (0.4-12\%). These fractions do not account for dissolved $\mathrm{N}_{2} \mathrm{O}$ lost via the effluent, which is usually negligible in highly aerated reactors (Kampschreur et al. 2009). In R1, the emission factor remained unchanged over the first two periods $(0.1-0.6 \%$ in $\mathrm{P} 1$ and $0.1-0.4 \%$ in $\mathrm{P} 2)$ but increased dramatically in P3 (0.2-12\%; Fig. 3). In R2, the emission factor increased with increasing proportions of blackwater in the inlet mixture $(0.4-1.8 \%$ in $\mathrm{P} 1$; $2.5-3.7 \%$ in $\mathrm{P} 2$ and $8.4-12.4 \%$ in P3; Fig. 4). Overall, the emission factor of both reactor tanks was $0.7 \%$ in P1 which is in the range of emission factors reported for biological wastewater treatment systems (Kampschreur et al. 2009), while it increased to values of $1.1 \%$ in P2 and $8.5 \%$ in $\mathrm{P} 3$, indicating an exponential increase of
$\mathrm{N}_{2} \mathrm{O}$ emissions with increasing blackwater content in wastewater.

Ex-situ studies

Batch trials with bulk liquid mixtures in closed incubation bottles and open bench-scale reactor

The interaction between decompostion of organics, biological $\mathrm{N}$ transformations, and $\mathrm{N}$ gas emissions in $\mathrm{R} 2$ was investigated in more detail in closed batch incubations and in an open bench-scale reactor run in batch modus. For both systems, biofilm grits from the first two loading periods $(\mathrm{P} 1, \mathrm{P} 2)$ were used together with reactor bulk liquid mixtures representing typical loading conditions for R2 (Table 2).

$J_{\mathrm{NH}_{4} \text { oxi }}$ in bulk liquid incubations was two to three times higher than the maximum $J_{\mathrm{NH}_{4} \mathrm{oxi}}$ observed in the second reactor tank during P1 and P2 (compare Figs. 4, $5 \mathrm{a}$, ). The higher $J_{\mathrm{NH}_{4} \text { oxi }}$ rates can be attributed to the higher DO in the stirred incubations which was estimated to be $6-8 \mathrm{mg} \mathrm{L}^{-1}$ based on observed $\mathrm{O}_{2}$ depletion in the headspace (data not shown) and the $\mathrm{O}_{2}$ transfer rate to the stirred medium provided by Molstad et al. (2007). Open batch trials run in parallel showed a comparable $J_{\mathrm{NH}_{4} \text { oxi }}$ when the DO was adjusted to the DO level estimated for the incubation bottles (data not shown). The open batch trials carried out in parallel to the bottle incubations showed that readily biodegradable soluble organics were depleted within $2 \mathrm{~h}$ in $\mathrm{P} 1\left(80 \mathrm{mg} \mathrm{O}_{2} \mathrm{~L}^{-1}\right)$ and within $1 \mathrm{~h}$ in $\mathrm{P} 2\left(50 \mathrm{mg} \mathrm{O}_{2} \mathrm{~L}^{-1}\right)$ (Fig. 5d, e). Additional samples taken after $24 \mathrm{~h}$ showed that a further COD depletion of $40 \mathrm{mg} \mathrm{O}_{2} \mathrm{~L}^{-1}$ in $\mathrm{P} 1$ and $70 \mathrm{mg} \mathrm{O}_{2} \mathrm{~L}^{-1}$ in $\mathrm{P} 2$ took place at low but relatively constant rates of 6-7 $\mathrm{mg} \mathrm{O}_{2} \mathrm{~m}^{-2} \mathrm{~h}^{-1}$ and $10-11 \mathrm{mg} \mathrm{O}_{2} \mathrm{~m}^{-2} \mathrm{~h}^{-1}$, respectively (not shown). These data suggest that $\mathrm{J}_{\mathrm{COD}}$ measured in the bulk liquid incubations represented both readily and slowly degradable organics, and that, a markedly higher proportion of these organic substrates $(70 \%)$ was readily degradable in P1 (mixture of $80 \%$ greywater; $20 \%$ blackwater) as compared to only $40 \%$ in P2 (mixture of $50 \%$ greywater; $50 \%$ blackwater). The COD degradation data from the open batch trials can also be used to approach the residual $S_{\text {org }}$ in R2 which was $<5 \mathrm{mg} \mathrm{O}_{2} \mathrm{~L}^{-1}$ in $\mathrm{P} 1$ and around $10 \mathrm{mg} \mathrm{O}_{2} \mathrm{~L}^{-1}$ in $\mathrm{P} 2$, supporting the assumption of a strong substrate limitation of the heterotrophic acitivity in the second reactor tank (see "Nitrification activity and controlling factors" section).

Assuming that the observed imbalance between disapperaing TAN and appering $\mathrm{NO}_{2}{ }^{-}, \mathrm{NO}_{3}{ }^{-}, \mathrm{NO}$, and $\mathrm{N}_{2} \mathrm{O}$ was due to denitrification, the total gaseous $\mathrm{N}$ loss in the closed incubations bottles was higher in P2 (B1, 25-50 \% 


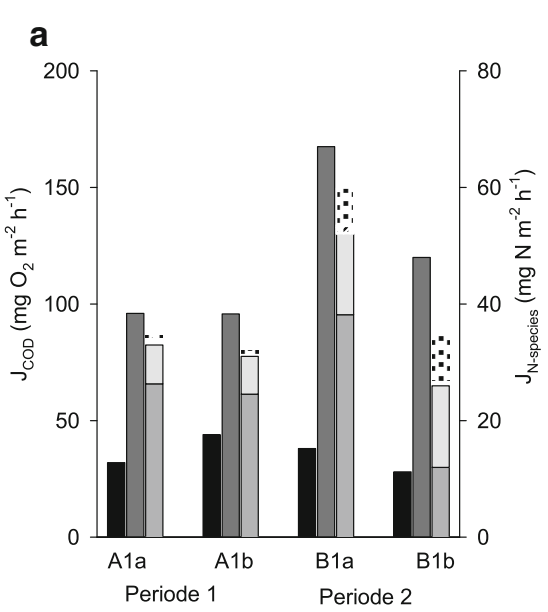

b

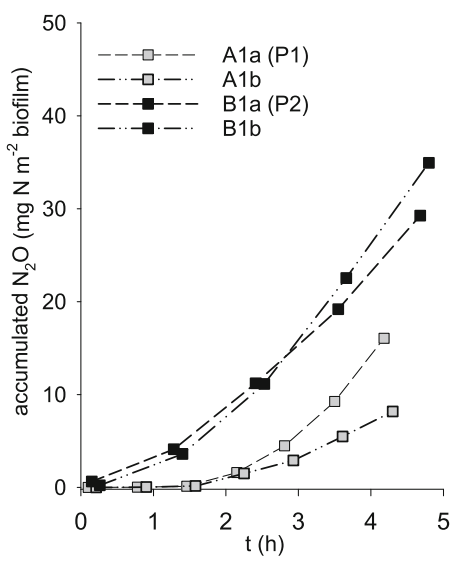

C

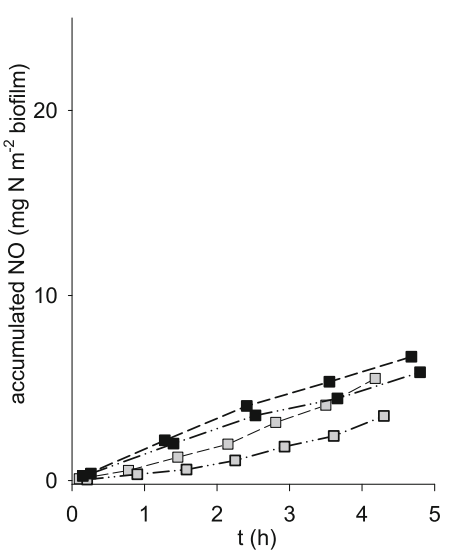

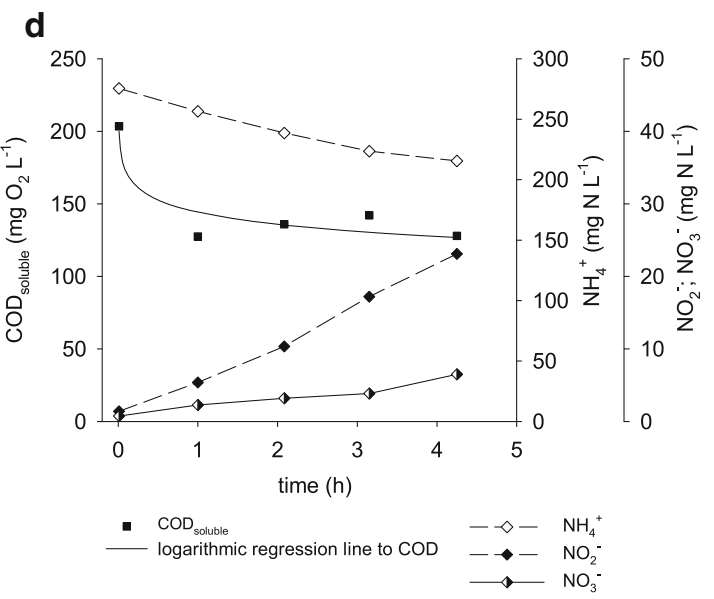

Fig. 5 Upper panel a average flux of $\mathrm{COD}$, , TAN, $\mathrm{NO}_{2}{ }^{-}$ $\mathrm{NO}_{3}{ }^{-}$, NO and $17 \pi \mathrm{N}_{2} \mathrm{O}$ throughout 5-h incubation in closed stirred bottles; the left column refers to COD (secondary $y$ axis); the middle column refers to disappearing and the right column to appearing $\mathrm{N}$ compounds (primary $y$-axis). Shown are two replicate incubations per treatment $(a, b), \mathbf{b}$ accumulation of $\mathrm{N}_{2} \mathrm{O}$ and $\mathbf{c} \mathrm{NO}$ expressed in $\mathrm{mg} \mathrm{N}$ per $\mathrm{m}^{2}$ biofilm. Lower panel time course of bulk

of $J_{\mathrm{NH}_{4} \text { oxi }}$ ) than in P1 (A1, 17-23\%; Fig. 5a). The accumulation of $\mathrm{N}_{2} \mathrm{O}$ in the batch incubations followed exponential kinetics (Fig. 5b), while the accumulation of NO followed a linear pattern, especially in P2 (Fig. 5c), indicating that the two gases may have originated from different processes. In $\mathrm{P} 1$ (A1), $\mathrm{N}_{2} \mathrm{O}$ production accounted for 2-3\% of $J_{\mathrm{NH}_{4} \text { oxi }}$ and was almost negligible during the first $2 \mathrm{~h}$ before it increased exponentially (Fig. 5b). The incubation of P2 (B1) showed similar kinetics, but a markedly higher fraction of 9-16\% of $J_{\mathrm{NH}_{4} \text { oxi }}$ was converted to $\mathrm{N}_{2} \mathrm{O}$ (Fig. 5b). The increasing $J_{\mathrm{N}_{2} \mathrm{O}}$ was likely paralleled by a decreasing COD flux as shown in open batch experiments in both periods and increasing $\mathrm{NO}_{2}{ }^{-}$concentrations (Fig. 5d, e). In summary, the presence of $\mathrm{NO}_{2}{ }^{-}$seemed to stimulate $\mathrm{N}_{2} \mathrm{O}$

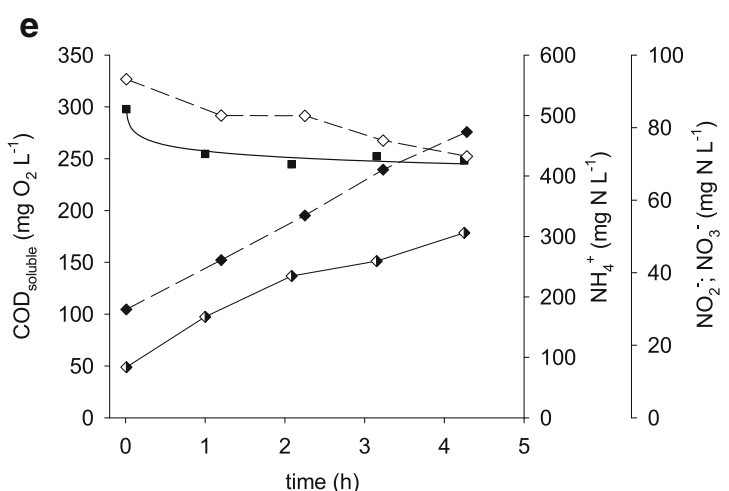

liquid concentrations of soluble organics (COD), $\mathrm{NH}_{4}{ }^{+}, \mathrm{NO}_{2}{ }^{-}$, and $\mathrm{NO}_{3}{ }^{-}$throughout a 4-h batch incubation in an open bench-scale MBBR reactor loaded with $\mathbf{d}$ bulk liquid mixture from the first loading period and e bulk liquid mixture from the second loading period. The COD data points were fitted to a logarithmic regression line

production, while the presence of readily degradable organics reduced $\mathrm{N}_{2} \mathrm{O}$ production.

\section{Batch incubations with enhanced organic load and added} $\mathrm{NO}_{2}{ }^{-}$

Additional incubations were carried out with material from P2 to investigate the impact of $\mathrm{NO}_{2}{ }^{-}$and two different types of high organic load; an inlet mixture with real wastwater (inlet incubation) and a synthetic mixture enriched with acetate (acetate incubation; Table 2).

In these experiments $(\mathrm{C} 1,2$ : inlet mixture and D1: acetate in Fig. 6), $\mathrm{J}_{\mathrm{COD}}$ was tenfold higher than in the previous bulk liquid incubations (Fig. 5a), while $J_{\mathrm{NH}_{4} \text { oxi }}$ was markedly reduced (compare Figs. 6a, 5a). The addition of 


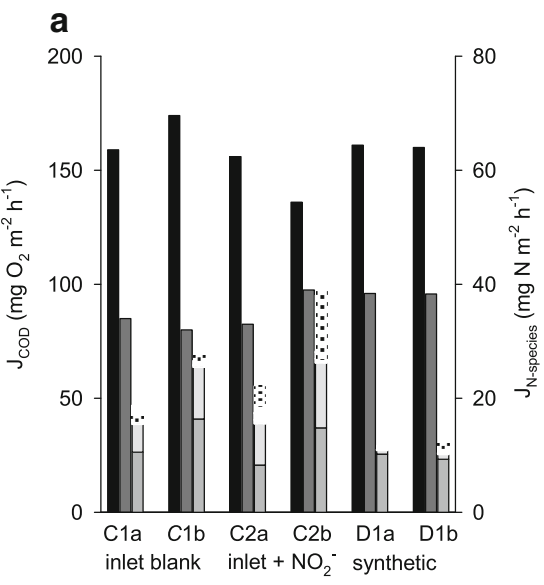

Fig. 6 Average flux of COD, $\square$, TAN, $\mathrm{NO}_{2}{ }^{-}-\mathrm{NO}_{3}{ }^{-} \square$, $\mathrm{NO}$ and $\mathrm{N}_{2} \mathrm{O}$ throughout 5-h incubation in closed stirred bottles; the left column refers to COD (secondary $y$-axis); the middle column refers to disappearing and the right column to appearing $\mathrm{N}$ b

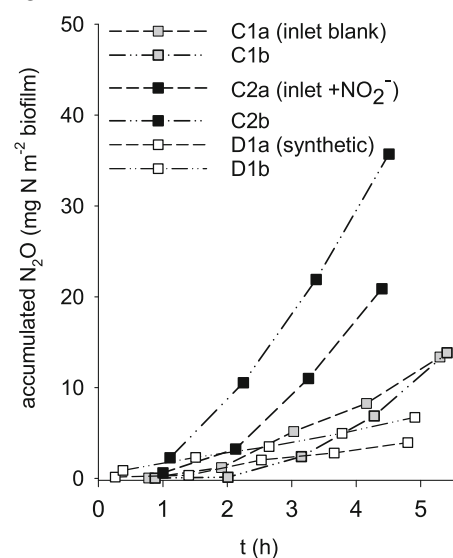

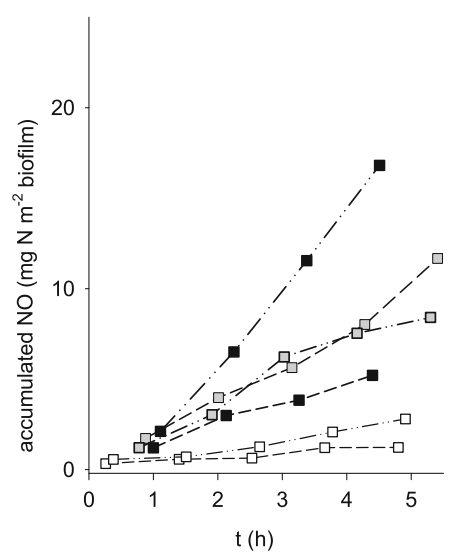

compounds (primary $y$-axis). Shown are two replicate incubations per treatment $(\mathbf{a}, \mathbf{b}), \mathbf{b}$ accumulation of $\mathrm{N}_{2} \mathrm{O}$ and $\mathbf{c} \mathrm{NO}$ expressed in $\mathrm{mg} \mathrm{N}$ per $\mathrm{m}^{2}$ biofilm

$\mathrm{NO}_{2}{ }^{-}$did neither affect $\mathrm{J}_{\mathrm{COD}}$ nor $J_{\mathrm{NH}_{4} \text { oxi }}$. The inlet incubations (C1, C2; Fig. 6a) showed a total gasesous $\mathrm{N}$ loss comparable to the bulk liquid incubation of P2 (B1, Fig. 5a), regardless whether $\mathrm{NO}_{2}{ }^{-}$was added or not. Conversely, the acetate incubation (D1) showed a substantialy higher total gaseous $\mathrm{N}$ loss accounting for $\sim 80 \%$ of $J_{\mathrm{NH}_{4} \text { oxi }}$ (Fig. $6 \mathrm{c}$ ). At the same time, the acetate incubation showed the greatest apparent denitrification among all treatments. This suggests that more electron donors were provided to anoxic biofilm zones with the acetate medium, likely because of the smaller molecule size and higher diffusity of acetate. Moreover, the wastewater mixtures used in our study may have contained slowly degradable substrates as shown by the open batch trial (see "Batch trials with bulk liquid mixtures in closed incubation bottles and open bench-scale reactor" section), which would reduce the denitrification rates compared to acetate.

$\mathrm{N}_{2} \mathrm{O}$ accumulation in incubations with inlet and synthetic mixture without added $\mathrm{NO}_{2}{ }^{-}(\mathrm{C} 1, \mathrm{D} 1)$ was negligible during the first $2 \mathrm{~h}$ (Fig. 6b), and the lag phase was clearly longer than in incubations with bulk liquid and biofilm from the same loading period (B1; Fig. 5b). In contrast, the loading regime did not seem to have any effect on the kinetics of $\mathrm{NO}$ accumulation (compare Figs. 5c, 6c). Addition of $\mathrm{NO}_{2}{ }^{-}$clearly stimulated $\mathrm{N}_{2} \mathrm{O}$ accumulation (Fig. 6b) but showed no consistent effect on $\mathrm{NO}$ accumulation. On the other hand, $\mathrm{NO}$ accumulation in the incubation with acetate was significantly smaller (Fig. 6c), suggesting that also NO production might depend on the type of organic substrate load. $J_{\mathrm{N}_{2} \mathrm{O}}$ accounted for 6-7\% of $J_{\mathrm{NH}_{4} \text { oxi }}$ in incubations with inlet mixture and 2-3\% with acteate (C1, Fig. 6a), which is markedly lower than the 9-16\% observed in incubations with bulk liquid taken from the same period (B2, Fig. 5a). These results reaffirm the finding from the bulk liquid incubations that elevated $\mathrm{NO}_{2}^{-}$increases, while readily degradable organics decrease $\mathrm{N}_{2} \mathrm{O}$ production in the biofilm.

Potential mechanism for $\mathrm{N}_{2} \mathrm{O}$ emissions

$\mathrm{N}_{2} \mathrm{O}$ production in municipal wastewater treatment plants has been reported to be greatest at high $\mathrm{NH}_{4}{ }^{+}$oxidation rates (Law et al. 2012; Upadhyay et al. 2006; Wunderlin et al. 2012) and has been attributed to the oxidation of intermediates released during $\mathrm{NH}_{4}{ }^{+}$oxidation (e.g. $\mathrm{NOH}$, $\mathrm{NO}) . J_{\mathrm{NH}_{4} \text { oxi }}$ in our reactors was five to ten times lower than rates reported from biofilm systems designed for nitrification (e.g. Elenter et al. 2007; Fux et al. 2004). Therefore, it is unlikely that oxidative processes during nitrification were the main source for $\mathrm{N}_{2} \mathrm{O}$ production. In our system, the emission of $\mathrm{N}_{2} \mathrm{O}$ was linked to $\mathrm{NO}_{2}{ }^{-}$accumulation (Fig. 2), and this was confirmed in incubation experiments with inlet mixture amended with $\mathrm{NO}_{2}{ }^{-}$, which accumulated significantly more $\mathrm{N}_{2} \mathrm{O}$ than without added $\mathrm{NO}_{2}{ }^{-}$ (Fig. 6b). $\mathrm{N}_{2} \mathrm{O}$ emissions observed at high $\mathrm{NO}_{2}{ }^{-}$concentrations are commonly attributed to nitrifier denitrification (Beaumont et al. 2002; Schreiber et al. 2009). Schreiber et al. (2009) determined a $\mathrm{NO}_{2}{ }^{-}$threshold of $2.8 \mathrm{mg}$ $\mathrm{N} \mathrm{L}^{-1}(200 \mu \mathrm{m})$ for a biofilm, above which nitrifier denitrification started to reduce $\mathrm{NO}_{2}{ }^{-}-\mathrm{N}_{2} \mathrm{O}$. In $\mathrm{R} 1, \mathrm{NO}_{2}{ }^{-}$ 
passed this threshold only during three distinct peaks in P2 and $\mathrm{P} 3$ which fell together with elevated $\mathrm{N}_{2} \mathrm{O}$ emissions. Also R2 showed $\mathrm{N}_{2} \mathrm{O}$ emission peaks coinciding with high $\mathrm{NO}_{2}{ }^{-}$(Fig. 2). However, in $\mathrm{R} 2, \mathrm{NO}_{2}{ }^{-}$was above the putative threshold concentration throughout the entire experiment, which does not preclude that increasing $\mathrm{NO}_{2}{ }^{-}$ concentrations above a threshold triggered more $\mathrm{N}_{2} \mathrm{O}$ emission. As shown by the open batch trials (Fig. 6), the proportion of readily degradable organics $\left(S_{\text {org }}\right)$ in the inlet decreased with an increasing fraction of blackwater in the wastewater, which is in accordance with earlier findings (Itokawa et al. 2001). The open batch trial also showed that the availability of readily degradable organics decreased from P1 to P3 (Fig. 5d, e) which explains the increasing $\mathrm{NO}_{2}{ }^{-}$accumulation and $\mathrm{N}_{2} \mathrm{O}$ emissions (Fig. 3, 4) by increased substrate limitation of heterotrophic activity and higher oxygen availability to nitrifying organism.

The presence of $\mathrm{NO}_{2}{ }^{-}$may also have triggered heterotrophic denitrification in anoxic biofilm zones, which likely took place in both reactor tanks as indicated by the $\mathrm{N}$ mass balance in the bulk liquid incubations. Obviously, this denitrification activity was fueled by small amounts of readily degradable organics that reached anoxic zones during the first $1-2 \mathrm{~h}$ of incubation (Fig. 5a, $\mathrm{d}$, e). With increasing incubation time, heterotrophic denitrification became likely increasingly fueled by organics with low degradability that might stem from the inlet or be produced by endogenous biomass decay. Itokawa et al. (2001) and Pan et al. (2013) showed that $\mathrm{N}_{2} \mathrm{O}$ emissions may be increased by the presence of slowly degradable substrates, since the reduction of $\mathrm{N}_{2} \mathrm{O}$ to $\mathrm{N}_{2}$ is kinetically less favorable than the reduction of $\mathrm{NO}_{3}{ }^{-}$(or $\mathrm{NO}_{2}{ }^{-}$) to $\mathrm{N}_{2} \mathrm{O}$ when electrons are a limiting (Richardson et al. 2009). Later during incubation, these slowly degradable organics were likely the sole electron donors present in anoxic biofilm layers and might have sustained denitrification with a high $\mathrm{N}_{2} \mathrm{O}$ to $\mathrm{N}_{2}$ product ratio. Similar conditions were present in the biofilm of $\mathrm{R} 2$ where substrate limited denitrification might have been an important additional source of $\mathrm{N}_{2} \mathrm{O}$ when $\mathrm{NO}_{2}{ }^{-}$accumulated under enhanced blackwater proportions in the load of the reactor tanks (Fig. 2).

$\mathrm{N}_{2} \mathrm{O}$ emissions from wastewater treatment are estimated to account for as much as $26 \%$ of the total greenhouse gas emissions of the anthropogenic water cycle (Kampschreur et al. 2009). Accordingly, there is an increasing focus on reducing $\mathrm{N}_{2} \mathrm{O}$ emissions when planning and operating municipal wastewater treatment plants (Kampschreur et al. 2009; Schreiber et al. 2012). Our study indicates that onsite wastewater treatment systems may represent substantial point sources for $\mathrm{N}_{2} \mathrm{O}$, especially on locations where an enhanced proportion of blackwater can be expected as for example on mountain refugees and other decentralized tourist facilities (Andreottola et al. 2003). Hence, not only municipal wastewater treatment plants but also decentralized sewer systems need to be critically assessed in terms of greenhouse gas emissions. More effort is needed to develop climate smart source separating sanitation, which has gained popularity due to its high efficiency in water and nutrient reuse (Larsen et al. 2009). However, the substantial $\mathrm{N}$ loss in form of $\mathrm{N}_{2} \mathrm{O}$ in our biofilm system when loaded with pure blackwater may outweigh such beneficial effects. A careful evaluation and selection of technologies is therefore needed for those novel sanitation approaches to avoid adverse greenhouse gas emissions.

\section{Conclusion}

In view of natural loading variations, biological nitrogen conversion seems inevitable in biofilm systems loaded with household wastewater regardless whether the system is designed for nitrogen removal or not. In our study, nitrogen fluxes increased with increasing blackwater content, dominated by partial nitrification leading to $\mathrm{NO}_{2}{ }^{-}$accumulation. $\mathrm{N}_{2} \mathrm{O}$ emission peaks coincided with $\mathrm{NO}_{2}{ }^{-}$accumulation, pointing at nitrifier denitrification as the main process of $\mathrm{N}_{2} \mathrm{O}$ production. However, $\mathrm{N}$ mass balances in closed batch experiments indicated that also denitrification may have contributed to the observed $\mathrm{N}_{2} \mathrm{O}$ production. To reconcile these observations, we interpreted our data with a simple conceptual biofilm model predicting oxygen limitation as a function of substrate availability. According to the model, higher proportion of slowly degradable organics contained in blackwater would allow for enhanced nitrification in outer biofilm layers while leading to incomplete denitrification to $\mathrm{N}_{2} \mathrm{O}$ in deeper biofilm layers. With $20 \%$ blackwater in the sewage, the emission factor for $\mathrm{N}_{2} \mathrm{O}$ was within the commonly reported range for biological wastewater treatment, but increased exponentially with increasing proportions of blackwater. A careful evaluation of suitable technologies is therefore needed for source separating sanitation approaches to avoid that adverse greenhouse gas emissions outweigh the benefits of water and nutrient reuse.

Acknowledgments This study was supported by the Norwegian Research Council (Grant No skattefunn-226774). A special thanks also to Associate Prof. Arve Heistad for the support to the pilot-scale experiment setup and Olga Popovic for helping with analysis work. 


\section{References}

Aarnink AJA, Elzing A (1998) Dynamic model for ammonia volatilization in housing with partially slatted floors, for fattening pigs. Livest Prod Sci 53:153-169. doi:10.1016/s03016226(97)00153-x

Andreottola G, Damiani E, Foladori P, Nardelli P, Ragazzi M (2003) Treatment of mountain refuge wastewater by fixed and moving bed biofilm systems. Water Sci Technol 48:169-177

Anthonisen AC, Loehr RC, Prakasam TBS, Srinath EG (1976) Inhibition of nitrification by ammonia and nitrous acid. J Water Pollut Control Fed 48:835-852

Azizi S, Valipour A, Sithebe T (2013) Evaluation of different wastewater treatment processes and development of a modified attached growth bioreactor as a decentralized approach for small communities. Sci World J. doi:10.1155/2013/156870

Beaumont HJE et al (2002) Nitrite reductase of Nitrosomonas europaea is not essential for production of gaseous nitrogen oxides and confers tolerance to nitrite. $\mathrm{J}$ Bacteriol 184:2557-2560. doi:10.1128/jb.184.9.2557-2560.2002

Daude D, Stephenson T (2003) Moving bed biofilm reactors: a smallscale treatment solution. Water Sci Technol 48:251-257

de Graaff MS, Zeeman G, Temmink H, van Loosdrecht MCM, Buisman CJN (2010) Long term partial nitritation of anaerobically treated black water and the emission of nitrous oxide. Water Res 44:2171-2178

Dulekgurgen E, Dogruel S, Karahan Ö, Orhon D (2006) Size distribution of wastewater COD fractions as an index for biodegradability. Water Res 40:273-282

Elenter D, Milferstedt K, Zhang W, Hausner M, Morgenroth E (2007) Influence of detachment on substrate removal and microbial ecology in a heterotrophic/autotrophic biofilm. Water Res 41:4657-4671. doi:10.1016/j.watres.2007.06.050

Fux C, Huang D, Monti A, Siegrist H (2004) Difficulties in maintaining long-term partial nitritation of ammonium-rich sludge digester liquids in a moving-bed biofilm reactor (MBBR). Water Sci Technol 49:53-60

Gujer W, Henze M, Mino T, van Loosdrecht M (1999) Activated sludge model no. 3. Water Sci Technol 39:183-193. doi:10. 1016/s0273-1223(98)00785-9

Hocaoglu SM, Insel G, Cokgor EU, Baban A, Orhon D (2010) COD fractionation and biodegradation kinetics of segregated domestic wastewater: black and grey water fractions. J Chem Technol Biotechnol 85:1241-1249. doi:10.1002/jctb.2423

ICCP (2001) Climate change 2001: the scientific basis. Cambridge University Press, New York

Itokawa H, Hanaki K, Matsuo T (2001) Nitrous oxide production in high-loading biological nitrogen removal process under low COD/N ratio condition. Water Res 35:657-664. doi:10.1016/ s0043-1354(00)00309-2

Kampschreur MJ, Temmink H, Kleerebezem R, Jetten MSM, van Loosdrecht MCM (2009) Nitrous oxide emission during wastewater treatment. Water Res 43:4093-4103. doi:10.1016/j.watres. 2009.03.001

Kindaichi T, Ito T, Okabe S (2004) Ecophysiological interaction between nitrifying bacteria and heterotrophic bacteria in autotrophic nitrifying biofilms as determined by microautoradiographyfluorescence in situ hybridization. Appl Environ Microbiol 70:1641-1650. doi:10.1128/aem.70.3.1641-1650.2004

Larsen TA, Alder AC, Eggen RIL, Maurer M, Lienert J (2009) Source separation: will we see a paradigm shift in wastewater handling. Environ Sci Technol 43:6121-6125. doi:10.1021/ es803001r

Law Y, Ni BJ, Lant P, Yuan ZG (2012) $\mathrm{N}_{2} \mathrm{O}$ production rate of an enriched ammonia-oxidising bacteria culture exponentially correlates to its ammonia oxidation rate. Water Res 46:3409-3419. doi:10.1016/j.watres.2012.03.043

Logan BE, Hermanowicz SW, Parker DS (1987) A fundamental model for trickling filter process design. J Water Pollut Control Fed 59:1029-1042

Molstad L, Dörsch P, Bakken LR (2007) Robotized incubation system for monitoring gases $\left(\mathrm{O}_{2}, \mathrm{NO}, \mathrm{N}_{2} \mathrm{O}, \mathrm{N}_{2}\right)$ in denitrifying cultures. J Microbiol Methods 71:202-211. doi:10.1016/j.mimet.2007.08. 011

Pan YT, Ni BJ, Yuan ZG (2013) Modeling electron competition among nitrogen oxides reduction and $\mathrm{N}_{2} \mathrm{O}$ accumulation in denitrification. Environ Sci Technol 47:11083-11091. doi:10. 1021/es402348n

Penn R, Hadari M, Friedler E (2012) Evaluation of the effects of greywater reuse on domestic wastewater quality and quantity. Urban Water J 9:137-148. doi:10.1080/1573062x.2011. 652132

Poth M, Focht DD (1985) N-15 kinetic-analysis of $\mathrm{N}_{2} \mathrm{O}$ production by Nitrosomonas europaea - an examination of nitrifier dentrification. Appl Environ Microbiol 49:1134-1141

Ravishankara AR, Daniel JS, Portmann RW (2009) Nitrous oxide $\left(\mathrm{N}_{2} \mathrm{O}\right)$ : the dominant ozone-depleting substance emitted in the 21st century. Science 326:123-125. doi:10.1126/science. 1176985

Richardson D, Felgate H, Watmough N, Thomson A, Baggs E (2009) Mitigating release of the potent greenhouse gas $\mathrm{N}_{2} \mathrm{O}$ from the nitrogen cycle-could enzymic regulation hold the key? Trends Biotechnol 27:388-397. doi:10.1016/j.tibtech.2009.03.009

Rittmann BE, Regan JM, Stahl DA (1994) Nitrification as a source of soluble organic substrate in biological treatment. Water Sci Technol 30:1-8

Schmidt I (2009) Chemoorganoheterotrophic growth of Nitrosomonas europaea and Nitrosomonas eutropha. Curr Microbiol 59:130-138. doi:10.1007/s00284-009-9409-8

Schreiber F, Loeffler B, Polerecky L, Kuypers MMM, de Beer D (2009) Mechanisms of transient nitric oxide and nitrous oxide production in a complex biofilm. ISME J 3:1301-1313. doi:10. 1038/ismej.2009.55

Schreiber F, Wunderlin P, Udert KM, Wells GF (2012) Nitric oxide and nitrous oxide turnover in natural and engineered microbial communities: biological pathways, chemical reactions, and novel technologies. Front Microbiol 3:24. doi:10.3389/fmicb. 2012.00372

Todt D, Heistad A, Jenssen PD (2014) Load and distribution of organic matter and nutrients in a separated household wastewater stream. Environ Technol. doi:10.1080/09593330.2014.997300

Upadhyay AK, Hooper AB, Hendrich MP (2006) NO reductase activity of the tetraheme cytochrome c (554) of Nitrosomonas europaea. J Am Chem Soc 128:4330-4337. doi:10.1021/ ja055183+

Wanner O, Reichert P (1996) Mathematical modeling of mixedculture biofilms. Biotechnol Bioeng 49:172-184

Wanner O, Eberl HJ, Morgenroth E, Noguera DR, Picioreanu C, Rittmann BE, van Loosdrecht MCM (2006) Mathematical modeling of biofilms. IWA Publishing, London

Wunderlin P, Mohn J, Joss A, Emmenegger L, Siegrist H (2012) Mechanisms of $\mathrm{N}_{2} \mathrm{O}$ production in biological wastewater 
treatment under nitrifying and denitrifying conditions. Water Res 46:1027-1037. doi:10.1016/j.watres.2011.11.080

Yang JJ, Trela J, Plaza E, Tjus K (2013) $\mathrm{N}_{2} \mathrm{O}$ emissions from a one stage partial nitrification/anammox process in moving bed biofilm reactors. Water Sci Technol 68:144-152. doi:10.2166/ wst. 2013.232
Zhang RH, Day DL, Christianson LL, Jepson WP (1994) A computermodel for predicting ammonia release rates from swine manure pits. J Agric Eng Res 58:223-229. doi:10.1006/jaer.1994.1052 